\title{
Corporate social responsibility for poverty alleviation: An integrated research framework
}

\author{
Rita D. Medina-Muñoz | Diego R. Medina-Muñoz (D)
}

Department of Economics and Management, University of Las Palmas de Gran Canaria, Las Palmas de Gran Canaria, Spain

\section{Correspondence}

Diego R. Medina-Muñoz, University of Las Palmas de Gran Canaria, Edificio de Empresariales, Módulo C-3.04, 35017 Las Palmas de Gran Canaria, Islas Canarias, Spain.

Email: dmedina@dede.ulpgc.es

\begin{abstract}
There is a growing demand by United Nations development agencies and governments for a higher engagement of firms in sustainable development goals, including that of eradicating poverty. Nevertheless, the social issue of poverty has not traditionally been covered by firms' corporate social responsibility (CSR) initiatives. In addition, there is a need to integrate theories in order to better explain pro-poor CSR in developing countries. Relying on a review of both conceptual and empirical research articles on CSR for poverty alleviation, this study contributes to the CSR research agenda by proposing an integrated research framework for assessing and explaining a firm's contribution to poverty alleviation. Besides discussing the existing evidence, the following issues are critically analysed with the general purpose of obtaining the framework and suggesting avenues for future research: the assessment of a firm's contribution to poverty alleviation, types of pro-poor CSR initiatives that could be adopted by firms, and the factors influencing a firm's contribution. The framework, which intends to be useful for future research, can also assist the United Nations to increase the firms' contribution to its alleviating poverty sustainable development goal.
\end{abstract}

\section{1 | INTRODUCTION}

Poverty represents an enormous global challenge and an indispensable requirement for sustainable development, particularly in developing countries (United Nations Division for Sustainable Development (UNDSD), 2015; World Commission on Environment \& Development, 1987). As a consequence, all actors in society, including firms, are expected to show goodwill and accept a level of responsibility in alleviating poverty (Barkemeyer \& Figge, 2014; Hahn, 2012; Pater \& van Lierop, 2006; Raimi, Akhuemonkhan, \& Ogunjirin, 2015). In that respect, the 2030 United Nations Agenda for Sustainable Development places emphasis on both the engagement of firms in solving sustainable development challenges, one of which is poverty eradication, and on the promotion of effective public-private partnerships to achieve this end.

Nowadays, it is assumed that firms contribute to reducing poverty by positively affecting economic growth (e.g., in terms of employment, investment or tax income for a community). Nevertheless, economic growth has not been inclusive and the absolute number of poor has increased (United Nations Conference on Trade and Development (UNCTAD), 2014). As a result, there is growing debate over the role of firms in poverty reduction, in particular of multinationals operating in less developed countries (e.g., Banerjee, 2018; Barkemeyer, 2009; Blowfield \& Frynas, 2005; Idemudia \& Osayande, 2016). Consequently, there is a need for further evidence concerning corporate social contribution to poverty alleviation. Moreover, the complexity of measuring a firm's contribution suggests the need to identify relevant research methods (MedinaMuñoz, Medina-Muñoz, \& Gutiérrez-Pérez, 2016; Wood, 2010). In this context, the term "corporate social responsibility" (CSR) is often adopted to acknowledge the non-economic dimension of business activity (Blowfield \& Frynas, 2005, p. 503): "companies have a responsibility for their impact on society and the natural environment, sometimes beyond legal compliance and the liability of individuals". 
However, the social issue of poverty alleviation has not been adequately covered by firms' CSR initiatives and sustainable management practices (Barkemeyer, 2009; Barkemeyer \& Figge, 2014; Hahn, 2012; Lobel, 2013). As regards the CSR for poverty as a research topic, there is a need to integrate theoretical approaches with the purpose of better explaining CSR in developing countries and to generate further empirical evidence (Barkemeyer, 2009, 2011; Frynas \& Yamahaki, 2016; Jamali \& Carroll, 2017). Considering the contributions to the special issue "Capturing advances in CSR: developed versus developing perspectives", which was published in the journal "Business Ethics: A European Review", Jamali and Carroll (2017) highlighted differences in the application of CSR across developed and developing countries in terms, for instance, of different perceptions of stakeholders (Griffin, 2017), "win-win" interpretations of CSR (Voltan, Hervieux, \& Mills, 2017) and of external factors influencing a firm's CSR (Vashchenko, 2017). More recently, Renouard and Ezvan (2018) argued that firms have to assume their social responsibility towards human development and sustainable development challenges (e.g., poverty eradication) even if it limits their economic performance. Accordingly, since poverty alleviation is a pressing social need that affects developing countries and the most vulnerable members of the community, firms are expected to adopt pro-poor CSR initiatives. Moreover, the application of CSR for poverty alleviation, as compared with CSR for other sustainable development challenges, might show some peculiarities (Griffin, 2017; Renouard \& Ezvan, 2018).

The main contribution of this paper to the CSR research agenda is an integrated research framework for assessing and explaining a firm's contribution to poverty alleviation. Building on a review of both conceptual and empirical research articles on CSR for poverty alleviation, the framework intends to be useful for facing the avenues that need to be urgently researched in the emerging academic literature on the role of the private sector in reducing poverty and for assisting the United Nations in achieving its poverty eradication goal. In order to obtain such a framework and suggest avenues for future research, the following issues will be considered: (a) the assessment of a firm's contribution to poverty alleviation; (b) types of pro-poor CSR initiatives (i.e., CSR initiatives for poverty alleviation) that could be adopted by firms and (c) the factors influencing a firm's contribution as the independent variables in the proposed model.

Accordingly, the first specific purpose of this study is to integrate conceptual and empirical research regarding the measurement of corporate social performance (CSP) in general and, in particular, of pro-poor CSP, as the dependent variable in the model. As conceived by Wood (1991, 2010), the term "CSP" refers to the CSR impacts and outcomes for society, stakeholders and the firm itself. In line with that definition, "pro-poor CSP" can be defined as the CSR impacts and outcomes for the poor. In so doing, besides considering the works of Wood, the different approaches to the measuring of a firm's contribution to poverty alleviation that have been adopted by empirical studies will be identified and critically compared. Empirical evidence concerning the contribution of firms in different geographical and business contexts will also be discussed. The second specific purpose is to work out an integrated list of pro-poor CSR initiatives that have been analysed by empirical studies. The list could be useful for assisting not only firms to increase their contribution to reducing poverty, but also researchers interested in developing a validated measurement scale for pro-poor CSP. A final specific purpose is to integrate the different factors suggested by both conceptual and empirical studies when explaining the business role in poverty alleviation (i.e., the independent variables in the model). As concluded by Frynas and Yamahaki (2016), more research is needed on integrating theories related to external and internal drivers of CSR. Along with general factors suggested by major CSR theoretical frameworks such as the "win-win", stakeholder and legitimation approaches, this study will also highlight other specific factors that have been pointed out by conceptual and empirical studies.

\section{2 | CONCEPTUAL APPROACHES TO THE ROLE OF CSR IN POVERTY ALLEVIATION}

The purpose of this section is not to review the vast literature on CSR and related terms (e.g., CSP, corporate citizenship, corporate social responsiveness, corporate social commitment) per se, but to review the elements within the following CSR approaches that specifically address poverty alleviation in the context of CSR: CSP, winwin business case CSR, stakeholder perspective, institutional theory and the legitimacy perspective on CSR. As such, the literature on the classical economic approach to CSR (e.g., Arnold \& Valentin, 2013; Friedman, 1962) for instance, or that on the "base/bottom of the pyramid" (BoP) (e.g., Kolk, Rivera-Santos, \& Rufin, 2014; Prahalad, 2004; Prahalad \& Hammond, 2002; Prahalad \& Hart, 2002) will not be considered. In order to achieve the purpose of elaborating an integrated research framework for the contribution of firms to poverty alleviation, the discussion of conceptual studies will focus on two issues of the framework: (a) the assessment of a firm's contribution to poverty alleviation as the dependent variable and (b) the factors influencing it as the independent variables.

\subsection{Assessment of a firm's contribution to poverty alleviation}

CSP and outcome-oriented research can help understand a firm's impact on society, including its contribution to poverty alleviation (Griffin, 2017; Wood, 2010). Wood (1991, 2010) placed emphasis on the need to develop measurement models to assess the impact of a firm's CSR initiatives on others, that is, stakeholders and society, rather than on the firm itself. For the general purpose of this study, the CSP for the poor is of interest as part of society and a firm's stakeholders, that is, those who affect or are affected by the achievement of the firm's objectives, such as employees, customers, suppliers, community and the natural environment (Clarkson, 1995; Freeman, 1984). As argued by Wood (2010), CSP and, thus, CSP for the poor are controversial, ambiguous and difficult to research. Nevertheless, there is a need to make progress concerning 
the way in which to measure a firm's contribution to poverty alleviation. In that respect, firms in general and, in particular, multinationals, have been urged to make a net positive contribution to reducing poverty as part of their CSR (e.g., Merino \& Valor, 2011; Valor, 2012; UNCTAD, 2014; UNDSD, 2015).

While there is abundant empirical evidence regarding the financial effects of a firm's CSR initiatives, the existing knowledge about their consequences for the intended beneficiaries is scant (Banerjee, 2014; Blowfield, 2007; Idemudia, 2014; Idemudia \& Osayande, 2016; Rodrigo, Duran, \& Arenas, 2016). As pointed out by Blowfield (2007), Idemudia (2014) and Rodrigo et al. (2016), this is particularly true in the case of pro-poor CSR initiatives in developing countries. Three possible causes are suggested by Wood (2010): a) the lack of effective demand for firms to assess their contribution to social challenges, b) the complexity of establishing causality between a firm's CSR actions and major social challenges and c) the inaccessibility of good data to evaluate the impact of a firm's CSR on stakeholders and society. Nevertheless, there is agreement regarding the need to consider the expectations and opinions of the intended beneficiaries of a firm's CSR initiatives (e.g., the poor and local households in the case of pro-poor CSR) (Blowfield, 2007; Idemudia, 2011, 2014; Wood, 2010).

Taking all the above into consideration, the different approaches to measuring a firm's contribution to poverty alleviation that have been adopted by empirical studies will be identified and compared in the "Evidence for corporate social contribution to poverty alleviation" section. As recommended by Wood (2010), the range of propoor CSR initiatives that have been evaluated by empirical studies will also be identified as processes affecting the outputs generated by a firm's pro-poor CSR (e.g., the number of local people lifted out of poverty). In that respect, Idemudia $(2007,2011)$ argued that there is a need to move from a focus on CSR outcomes to a focus on CSR processes (e.g., the adoption of pro-poor CSR initiatives and factors influencing it). Consequently, the integrated list of pro-poor CSR initiatives could also be considered when developing a validated scale for assessing a firm's contribution to poverty alleviation.

\subsection{Factors influencing a firm's contribution to poverty alleviation}

The "win-win" approach to CSR suggests that a general internal driver of pro-poor CSR is a possible positive impact on a firm's economic performance (Falck \& Heblich, 2007; Porter \& Kramer, 2002). According to this approach, firms adopt CSR initiatives that simultaneously contribute to increasing long-term profits. While the empirical evidence regarding the impact of a firm's CSR initiatives on its economic performance shows contradictory findings, several studies identified a significant positive association (e.g., Luo \& Bhattacharya, 2006; Maignan \& Ferrell, 2000). In general, pro-poor CSR initiatives can positively influence long-term profits by their impact on firm reputation, value of the brand, firm goodwill, consumer satisfaction, attractiveness as an employer and employees' organisational commitment (Falck \& Heblich, 2007).
Nevertheless, there is a need to truly determine whether and when firms can profit by responding to the needs of society in general and, in particular, those of the poor (Renouard \& Ezvan, 2018; Voltan et al., 2017).

The stakeholder approach to CSR posits that the long-term survival of a firm depends on its ability to contribute to the welfare of a variety of internal and external stakeholders that affect or are affected by the achievement of the firm's objectives, or that show a direct or indirect interest in the firm (Clarkson, 1995; Freeman, 1984). Besides shareholders/owners, typical primary stakeholders include employees, suppliers, customers, the community and the natural environment (Clarkson, 1995). According to this approach, another driver of pro-poor CSR is to contribute to the welfare of local communities, including the poor. Pro-poor CSR should also embrace initiatives for the remaining primary stakeholders with the purpose, for example, of reducing poverty amongst employees and their households, and also preserving the natural environment of poor communities (Medina-Muñoz et al., 2016).

However, as discussed by Margolis and Walsh (2003), Blowfield (2005), Banerjee (2008, 2014), Barkemeyer (2009) and Griffin (2017), CSR theory and practice have focused on key stakeholders that might positively influence a firm's economic performance (e.g., shareholders, employees, customers). Banerjee (2014) even argues that firms invest few or no resources at all to serve the interests of marginalised stakeholders, including the poor. Ironically, as pointed out by Blowfield and Frynas (2005, p. 508), a firm's commitment to CSR might also lead the firm to consider the poor and other marginalised groups as a threat to that commitment: e.g., "major sporting goods companies, for instance, have reduced the outsourcing to smaller producers in part because it is difficult to monitor those facilities".

As suggested by the institutional theory and the legitimacy perspective on CSR, firms should engage in social responsibility initiatives beyond the legal requirements, such as poverty alleviation, with the purpose of gaining social acceptance or "social licence" to operate in the community (Frynas \& Yamahaki, 2016; Mclntyre, Murphy, Sirsly, 2015; Raimi et al., 2015; Vashchenko, 2017). This perspective predicts a growing alignment of CSR initiatives with social rules, norms and values, as well as with powerful organisations and interest groups in the society (Frynas \& Yamahaki, 2016; Jamali, Lund-Thomsen, \& Khara, 2017; Lobel, 2013; Vashchenko, 2017). As recently discussed by Banerjee (2018), power asymmetries between firms, governments, communities' representatives and the most vulnerable members of the communities (i.e., the poor) can even lead a firm to adopt CSR initiatives in favour of governmental officers and a community's representatives, rather than of the powerless poor.

As found by Frynas and Yamahaki (2016), stakeholder theory, institutional theory and legitimacy perspective dominate the theorising of external drivers of CSR in general. Besides the factors influencing a firm's contribution to poverty alleviation that have been mentioned above, other drivers of pro-poor CSR have been suggested by conceptual studies. First, corporate headquarters seem to promote a Northern CSR agenda, rather than a Southern agenda 
that empowers the poor and other local stakeholders in developing countries (e.g., Barkemeyer \& Figge, 2014; Idemudia, 2011).

Second, as discussed by Idemudia (2011), different contexts in terms of economic, social, cultural and environmental conditions show different challenges for CSR practices. Accordingly, the higher the poverty rate in a region, the greater the importance of adopting pro-poor CSR initiatives should be. In addition, local ethics and morality should guide the design and implementation of pro-poor CSR initiatives. Third, the inability and/or unwillingness of governments and other civil society entities (e.g., development agencies, non-governmental organisations, NGOs) to fulfil the role of alleviating poverty leads firms to play an active role in initiating social policies and community development projects in favour of the poor, particularly in developing countries (e.g., Amadi \& Abdullah, 2012; Idemudia, 2011; Ite, 2004; Jamali, Lund-Thomsen, \& Jeppesen, 2017). This is apparent when corruption is extensive (Idemudia, 2011). In the case of multinationals, the government of the country of origin could also promote a pro-poor CSR agenda overseas (Idemudia \& Kwakyewah, 2018).

Lastly, since sustainable development goals such as poverty alleviation are often incompatible with the narrower corporate goal of shareholder value, a regulatory system has also been suggested as a driver of pro-poor CSR (Bakan, 2004; Banerjee, 2014; Blowfield, 2005). By arguing that poverty represents a violation of human rights and that CSR is linked to human rights, Osuji and Obibuaku (2016) concluded that CSR, including pro-poor CSR initiatives, can be regulated by law with the purpose of enforcing rights and, thus, restricting the use of CSR initiatives for attaining corporate self-interest.

\section{3 | EVIDENCE FOR CORPORATE SOCIAL CONTRIBUTION TO POVERTY ALLEVIATION}

Research articles with empirical evidence on CSR for poverty alleviation, along with conceptual articles with arguments and guidance for future research on this research topic, were searched in the peerreviewed journals listed in the electronic databases Elsevier's Scopus and Thomson Reuters's Web of Science, which are considered the world's largest abstract and citation databases. The words used in the meta-search of articles were "CSR" (or "corporate citizenship", "corporate social responsiveness", "corporate social commitment", "CSP", "shared value") and "poverty" (or "development", "developing countries", "empowerment"), and they were required to be in the title, abstract or keywords. Besides the conceptual articles that have already been discussed in the previous section of the manuscript, a total of 24 research articles with empirical evidence were finally selected for further analysis in this section. They have all been published since the year 2005, which confirms the novelty of this research topic.

Each of the selected empirical studies was first analysed to report its business scope (i.e., types of firms, economic sectors) and geographical scope (see Table 1). The different issues forming part of the integrated research framework intended as a guide for future empirical research were then identified and compared: (a) assessment of a firm's contribution to poverty alleviation; (b) types of pro-poor CSR initiatives and (c) factors influencing the adoption of pro-poor CSR actions. As regards the assessment of a firm's contribution, the measurement of corporate social contribution to poverty alleviation and the sources of information adopted by each manuscript were considered. In addition, major findings on the overall contribution of firms to poverty reduction were compared. The results of the analyses will follow.

\section{1 | Business and geographical scope of the research}

As displayed in Table 1, while 7 studies analysed the contribution to poverty of firms in general, the remaining 17 studies focused on particular types of firms: multinationals (12 studies), large companies (3), small-sized farms (1) and multinationals and small-sized firms (1). A total of 10 studies examined the commitment of firms in a variety of economic sectors in a specific location or database. Those sectors that received special attention in the remaining studies are: energy and minerals sectors (eight studies), the tour operating sector (two), the food and beverage sector (two), the lodging sector (one), banking and construction industries (one) and the sugarcane industry (one).

Africa is the leading continent in the empirical research on CSR for poverty alleviation (13 of the 24 studies made reference to African countries): Nigeria (7), South Africa (2), Kenya (1), Namibia (1), Mauritius (1) and Zimbabwe (1). Empirical evidence is also available for Argentina, Brazil, Cambodia, Colombia, India, Mexico, the United Kingdom, the United States of America and Vietnam. It is also relevant to emphasise the variety of geographical levels that were covered: international (i.e., firms in a variety of countries), national (i.e., firms in one particular country), regional (i.e., firms in one or several regions) and local (i.e., firms in one or several local communities).

\section{2 | The measurement of corporate social contribution to poverty alleviation}

Table 2 displays the study methods adopted by the selected empirical studies: (a) measurements of corporate social contribution to poverty alleviation; (b) secondary and primary sources of information. As pointed out by Kolk, Tulder, and Westdijk (2006) and Hahn (2012), there is no agreed method for measuring a firm's contribution to poverty alleviation. Three different measurement approaches were identified: (a) content analysis of CSR initiatives (11 studies); (b) the overall perceptions of residents, households, other local key informants, employees, managers and/or firms' other stakeholders (e.g., governmental officials, NGOs) (10) and (c) the development and application of an assessment framework with a list of items (3).

The majority of the studies analysed CSR initiatives that were described in corporate websites and/or reports, including annual reports, CSR reports, specific CSR programmes, sustainability reports and codes of conduct. For instance, Valor (2012) examined whether multinationals were adopting CSR initiatives related to the following: 

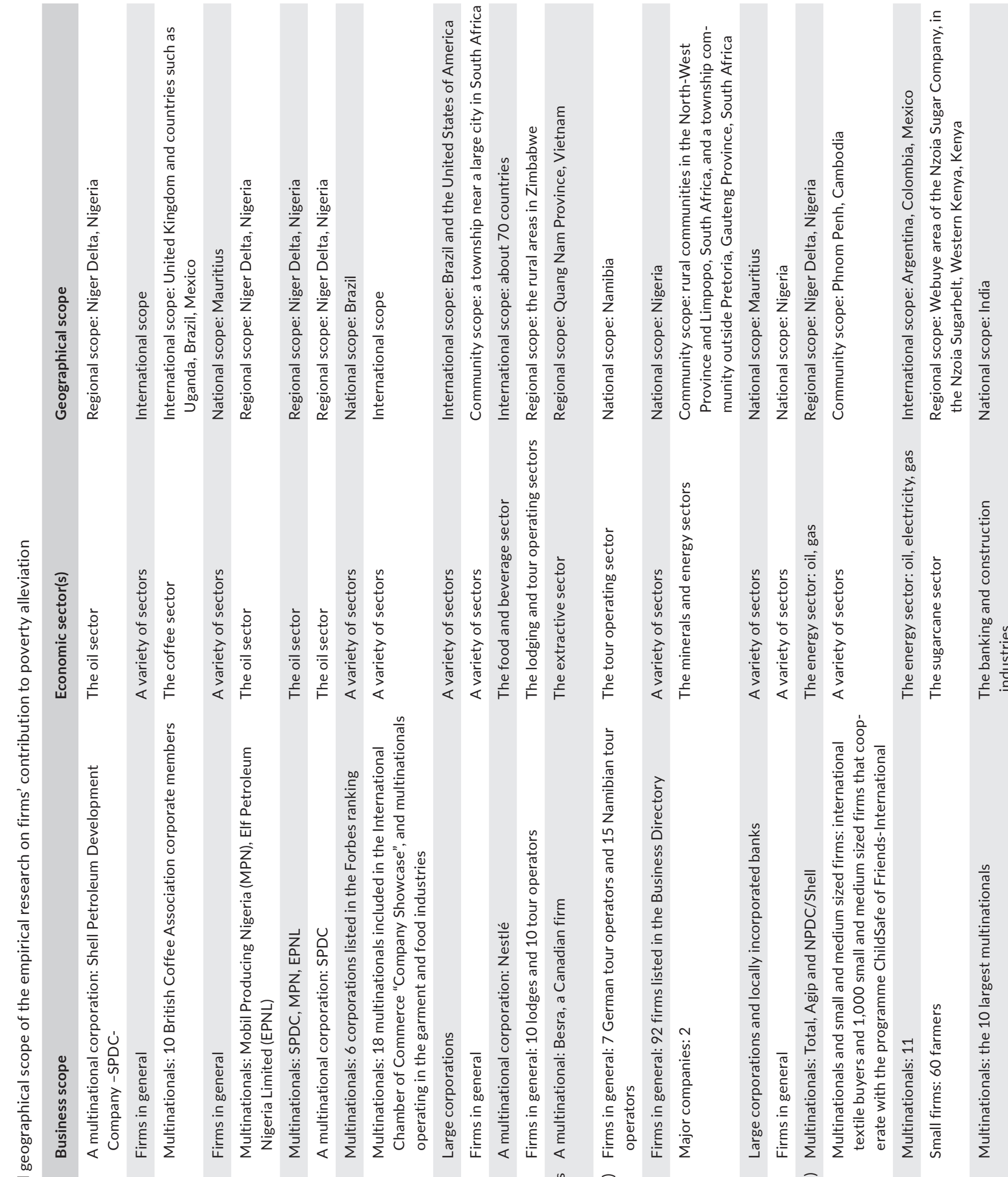

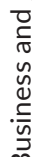

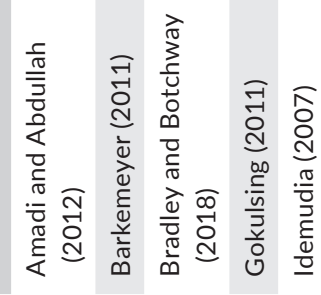

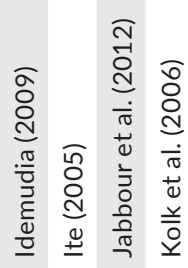
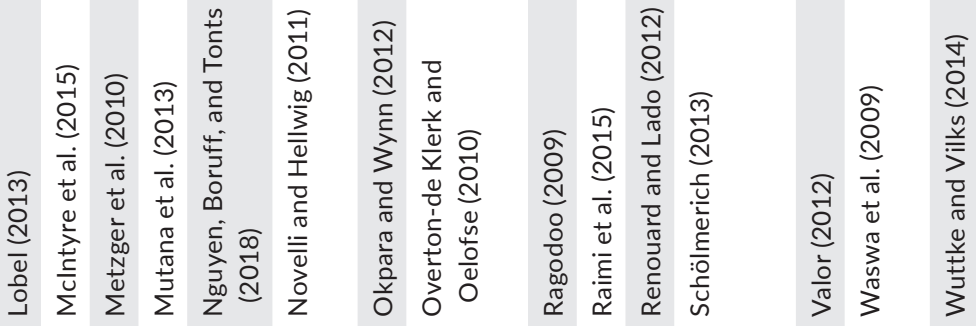


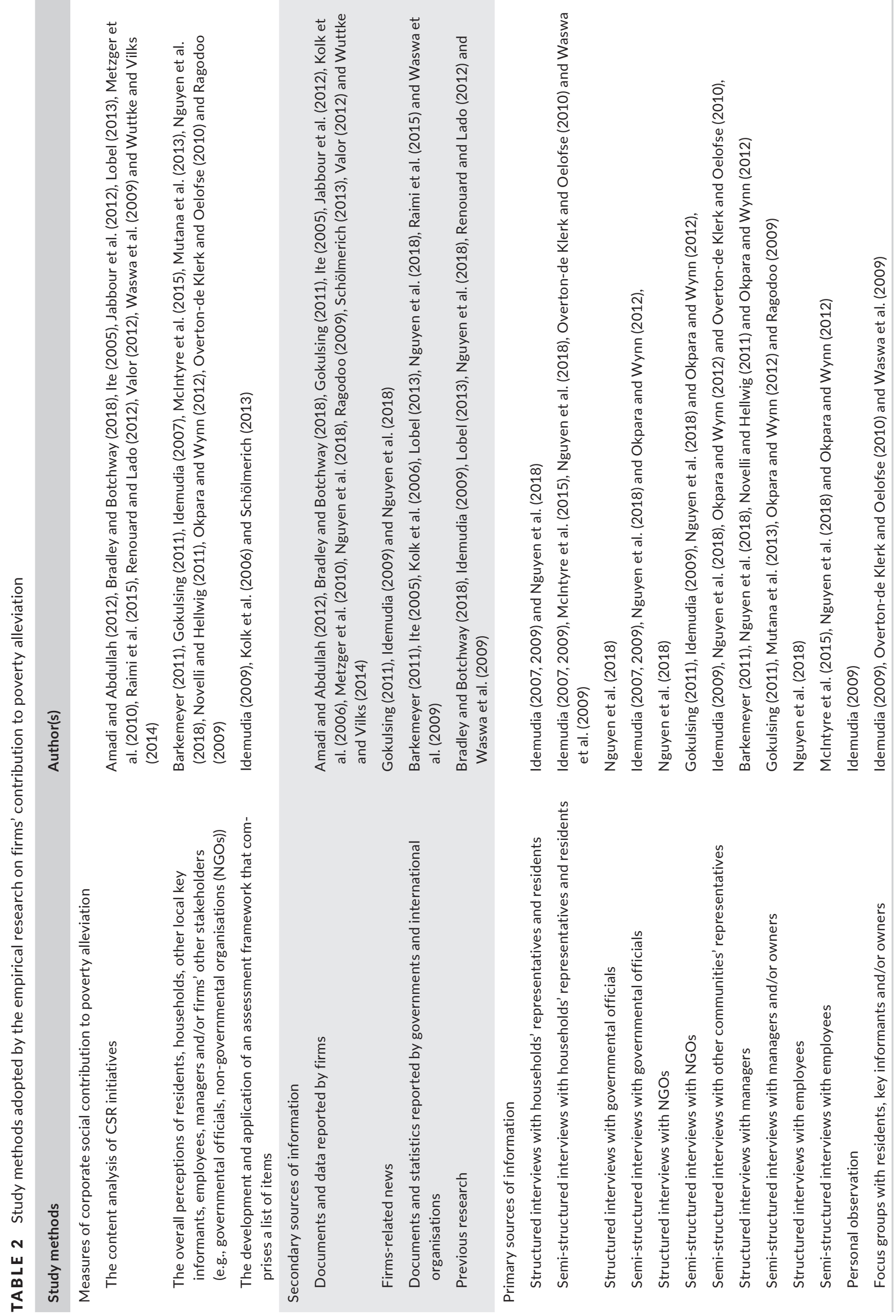


providing employment and living wages, stimulating community development, fighting malnutrition. Amadi and Abdullah (2012) critically evaluated the following CSR programmes: health care services, educational initiatives and a youth development scheme. Similarly, Wuttke and Vilks (2014) assessed four categories of CSR initiatives: infrastructure and community development, banning of child labour, gender equality and empowerment of female workers, environmental sustainability. Benchmark poverty alleviation practices were also considered by Lobel (2013).

The remaining studies that conducted content analysis of firms' reports placed emphasis on poverty alleviation in general as a reported CSR category (e.g., Bradley \& Botchway, 2018; Jabbour, Neto, Freitas, Teixeira, \& Silva, 2012; Metzger, Nunnenkamp, \& Mahmoud, 2010; Renouard \& Lado, 2012). The following indicators were also taken from three studies: CSR effort (Raimi et al., 2015), firms' community development expenditure (Ite, 2005), generation of income for local farmers (Waswa, Netondo, Maina, Naisiko, \& Wangamati, 2009). Considering all the above and the CSP framework developed by Wood (1991, 2010), it can be concluded that, with the exception of the research conducted by Waswa et al. (2009), content analysis of CSR initiatives has mainly focused on CSP processes, rather than on CSP outcomes.

A second approach was to ask for the overall opinion of firms' internal (managers, employees) and external stakeholders (residents, households, other local key informants, governmental officials, NGOs). As was pointed out in the review of conceptual studies, there is a need to ask the poor as the intended beneficiaries of a firm's propoor CSR initiatives (Blowfield, 2007; Idemudia, 2011, 2014; Wood, 2010). Nevertheless, only 6 of the 24 empirical studies conducted interviews or focus groups with local residents and households' representatives. All these studies also considered the opinions of one or several of the following stakeholders (see Table 2): governmental officials, NGOs, other local communities' representatives, managers and employees. Idemudia (2009) reported her own personal experience.

The most frequently used method for collecting opinions was by means of semi-structured interviews with a wide variety of groups. The use of semi-structured interviews and of qualitative research techniques (e.g., focus groups, personal observation), as compared with structured interviews, are justified by the complexity of measuring a firm's contribution to poverty alleviation. Besides residents and households' representatives, the following groups were considered: managers and owners (seven studies), employees (three), NGOs (four), governmental officials (three), other local communities' representatives (five).

A final approach was the development of an assessment framework composed of a list of items to evaluate a firm's contribution to poverty alleviation. This approach was adopted by only 3 of the 24 studies. Using reports published by the International Labour Organization, Organisation for Economic Co-operation and Development and UNCTAD, Kolk et al. (2006) developed a framework to evaluate corporate conduct in relation to the eradication of poverty. A total of 20 items were initially identified and then grouped into the following general and specific categories: content issues (equality of opportunity and treatment, working conditions, collective bargaining) and context issues (reflecting local conditions, dynamic comparative advantage, training, monitoring).

Idemudia (2009) identified affirmative duties for oil multinationals: improving socio-economic and cultural conditions (by reducing material deprivation and improving education and health) and building local capacity (by reducing voicelessness and powerlessness). Their negative duties refer to preventing and managing the negative impact of oil production on host communities. Finally, Schölmerich (2013) developed a list of 20 indicators to assess 10 capabilities to be promoted amongst the poor: income, education, empowerment of youth and women, health status, accommodation, labour conditions, access to the health care system, access to social networks, security and access to the legal system, access to capital, land and insurance.

A general evaluation of the three approaches suggests the need to carry out further research that aims to develop a reliable and validated scale for measuring a firm's contribution to poverty alleviation. As regards the use of the content analysis of corporate websites and/or reports, the results are affected by the amount and quality of the information reported. In that respect, pro-poor CSR initiatives might not be clearly described in corporate websites and reports. Besides, there are firms that do not publish structured information concerning their CSR initiatives. The overall perception of residents and other stakeholders as an approach to measuring a firm's commitment also shows a major limitation: results are affected by the stakeholders' understanding of poverty. Since poverty is a multidimensional phenomenon, the use of a list of items that aims to measure a firm's commitment to poverty alleviation seems more appropriate (e.g., a list of initiatives that a firm could adopt to reduce poverty). In so doing, the scales proposed by Kolk et al. (2006), Idemudia (2009) and Schölmerich (2013), as well as the list of propoor CSR initiatives that have been suggested by the 24 selected empirical studies, could all be taken into consideration. As was recommended by Blowfield (2007), Wood (2010) and Idemudia (2011, 2014), the opinions of the poor and local residents should also be considered when evaluating the selected items.

\section{3 | Firms' overall contribution to poverty alleviation}

A number of conclusions can be highlighted from the analysis of empirical studies on the role of multinationals in poverty alleviation. In line with what was proposed by Blowfield (2005), Valor (2012) found that energy sector multinationals are implementing CSR programmes in a reactive way (i.e., to face criticism arising from their activities in developing countries), rather than contributing to social challenges that are not linked to their core business (e.g., fighting malnutrition). Similarly, Kolk et al. (2006) reported that multinationals' commitment to poverty alleviation is not yet a priority in their CSR initiatives. These authors emphasise that, in general, only a few poverty-related issues are currently covered by multinationals' CSR strategies. Regarding Nestlé's aid budget allocation, Metzger et al. 
(2010) concluded that it favours developed countries, as compared with poor developing countries. More specifically, Bradley and Botchway (2018) found that only 1 of the 10 companies that were analysed reported initiatives to fight against poverty. Jabbour et al. (2012) even concluded that no CSR practice can be related to poverty alleviation.

Ite (2005), Idemudia (2007, 2009), Amadi and Abdullah (2012) and Renouard and Lado (2012) analysed the contribution of multinationals in the oil and gas sectors to reducing poverty in the Niger Delta, Nigeria. A general conclusion is that the increase in CSR expenses has not overcome poverty (Renouard \& Lado, 2012). Moreover, Idemudia (2007, 2009) concluded that multinationals can contribute to poverty reduction by not only investing in community development programmes, but also by ensuring that existing sources of development (e.g., farming, fishing) are not negatively affected by their operations. As recommended by Ite (2005) and Amadi and Abdullah (2012), the Nigerian government could invest a higher percentage of the tax income generated by the oil industry in poverty alleviation initiatives. In contradiction with Renouard and Lado's (2012) findings concerning multinationals' CSR, Okpara and Wynn (2012) and Raimi et al. (2015) concluded that entrepreneurship and CSR are adequate antidotes for poverty in Nigeria at the national level. These findings suggest that type of firm (e.g., multinationals, local firms) and economic sector (e.g., oil, tourism sectors) might influence a firm's contribution to poverty alleviation.

Considering the opinions of firms' management representatives from a wide variety of countries, Barkemeyer (2011) found that Southern respondents, as compared with Northern respondents, perceived that CSR has a higher potential to social issues in general and, in particular, to reducing poverty. From a list of 23 global challenges, he also concluded that business potential contribution to poverty is much lower than what is needed in terms of the perceived urgency of reducing poverty. In the case of major South African companies, Overton-de Klerk and Oelofse (2010) concluded that, while companies cannot escape from their accountability of reducing poverty, they cannot be expected to solve social problems and eradicate poverty. However, the inability and/or unwillingness of governments and other civil society entities to reduce poverty leads firms to play an active role (e.g., Amadi \& Abdullah, 2012; Idemudia, 2011; Ite, 2004; Jamali, Lund-Thomsen, \& Jeppesen, 2017).

As regards the contribution of Indian banking and construction multinationals to the Millennium Development Goals (MDGs), Wuttke and Vilks (2014) concluded that they focus on the reduction of extreme poverty and the environment. In the case of Mauritian firms, CSR is perceived as a necessary, but insufficient, tool to fight poverty (Gokulsing, 2011). Ragodoo (2009) also observed that: (a) poverty reduction is not amongst the Mauritian firms' CSR priorities and (b) the adoption of pro-poor initiatives is more apparent in the hotel, sugar, investment and banking sectors. In a South African city, almost $60 \%$ of the households interviewed considered that firms make decisions bearing in mind the welfare of residents (Mclntyre et al., 2015). In the case of tourism firms, Mutana, Chipfuva, and Muchenje (2013) found that $75 \%$ of the lodges and tour operators adopted a pro-poor approach to their business operations in rural Zimbabwe. Novelli and Hellwig (2011) concluded that Namibian and German tour operators' greatest contribution to the MDGs refers to poverty reduction.

Concerning small firms' commitment to poverty alleviation, Waswa et al. (2009) argued that although the introduction of sugarcane in the Nzoia Sugarbelt, Western Kenya, was generally expected to alleviate poverty by expanding farmers' income possibilities, poverty in this region remains endemic. They also placed emphasis on the need to promote pro-poor CSR initiatives. In the case of Phnom Penh, Cambodia, Schölmerich (2013) concluded that multinationals, as compared with small firms that collaborate with the programme ChildSafe, make a higher contribution to poverty reduction.

\section{4 | Types of pro-poor initiatives}

An integrated list of the pro-poor CSR practices that have been suggested by the selected empirical studies is put forward in this section (see Table 3). As was pointed out above, the list could be useful for measuring a firm's contribution to poverty alleviation. In fact, pro-poor CSR initiatives are processes affecting the outcomes generated by a firm's pro-poor CSR (e.g., the number of local people lifted out of poverty) (Idemudia, 2007, 2009; Wood, 2010). The first category of pro-poor initiatives is entitled "core business-related initiatives". Besides preventing and managing the negative impacts of the core business on the poor (Idemudia, 2009), firms could also facilitate their access to the affordable goods and services that meet basic needs (e.g., Okpara \& Wynn, 2012; Valor, 2012). For instance, firms could draw up commercial offers for the poor (Valor, 2012).

A second category of pro-poor practices (legitimation initiatives) refers to building relationships and collaborating with a community's stakeholders in order not only to reduce poverty but also to obtain legitimation to operate in the community (see Table 3). Since poor communities' stakeholders (e.g., public administration, trade unions, chambers of commerce, NGOs, community leaders) are quite knowledgeable about the conditions of the poor and the causes of poverty, Overton-de Klerk and Oelofse (2010) and Okpara and Wynn (2012) outlined the need to build relationships and collaborate with them. Similarly, Mclntyre et al. (2015) concluded that firms should collaborate with local stakeholders in order to identify a community's most pressing needs.

Two more categories of pro-poor initiatives are proposed by Kolk et al. (2006) and Lobel (2013), who distinguished between "internal CSR" (content and in-group CSR, respectively) and "external CSR" (context and universalist CSR, respectively). According to Lobel (2013), firms adopt in-group CSR initiatives to alleviate poverty amongst employees and other internal stakeholders, and universalist CSR initiatives aim to reduce poverty at the community level. Kolk et al. (2006) found that internal initiatives, which address content issues (equality of opportunity and treatment, working conditions, collective bargaining), as compared to external initiatives, which focus on context issues (reflecting local conditions, dynamic comparative advantage, training, monitoring), are more often adopted 


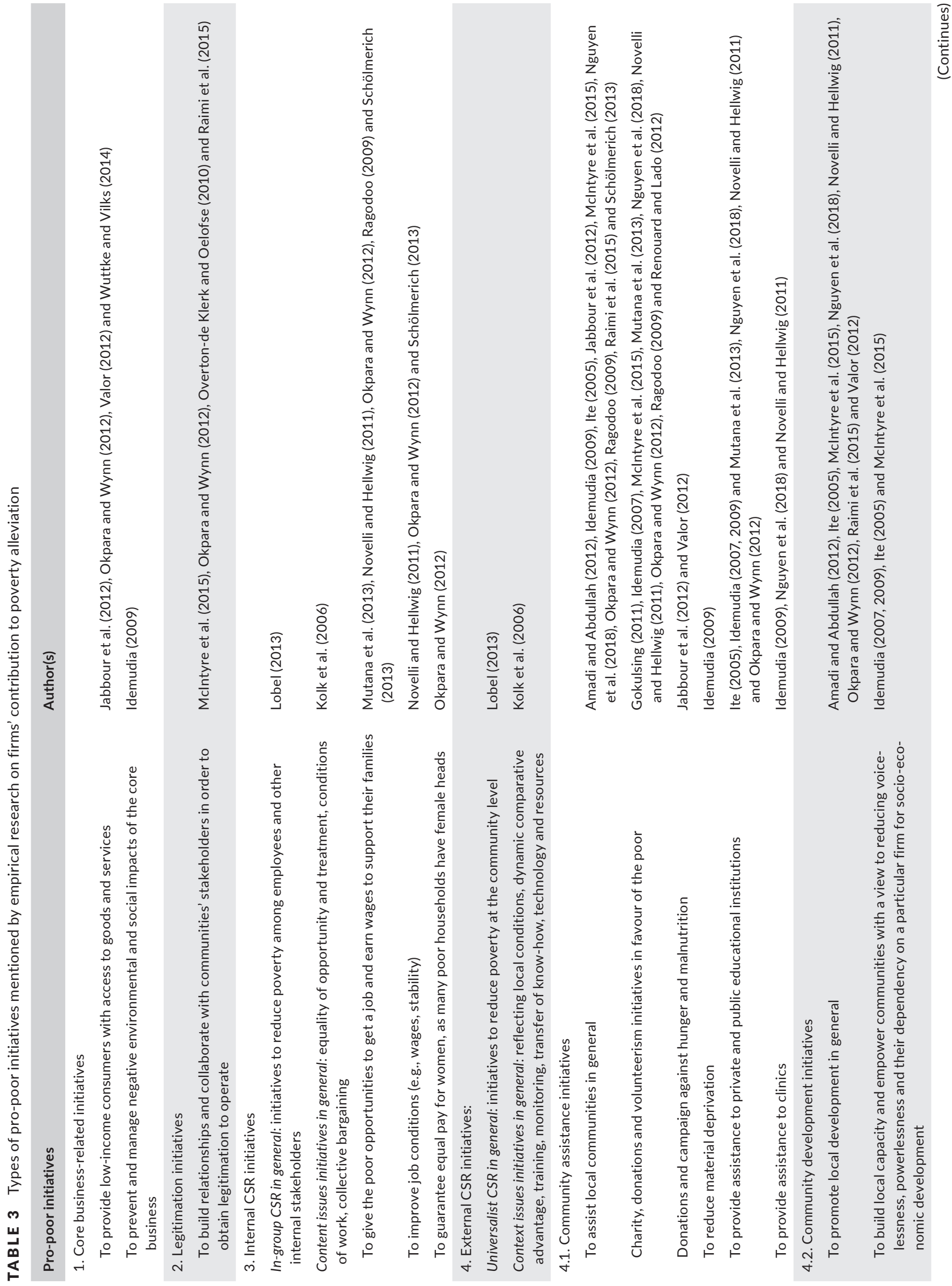


by multinationals. They also concluded that sustainable solutions to poverty can only be reached by covering context issues and, consequently, offering poor people adequate means (know-how, technology, resources) to escape the poverty status by themselves. As shown in Table 3, three specific internal CSR initiatives were suggested by the selected empirical studies: (a) giving the poor opportunities to get a job and earn wages to support their families; (b) improving job conditions (e.g., wages, stability) and (c) guaranteeing equal pay for women, as they are family heads in many poor households.

As regards external CSR initiatives, two more categories of propoor CSR initiatives were outlined by previous research (e.g., Amadi \& Abdullah, 2012; Ite, 2005; Mclntyre et al., 2015; Raimi et al., 2015): community assistance and community development initiatives. The most cited community assistance initiatives are (see Table 3): assisting local communities in general, participating in donations and volunteerism initiatives in favour of the poor, providing assistance to educational institutions and clinics, participating in campaigns against hunger and malnutrition and making financial contributions to material deprivation.

As shown in Table 3, a wide variety of community development initiatives were also mentioned: community development programmes in general, building local capacity and empowering communities, education and training initiatives, for example, building schools, paying school fees, employment generation, income generation for local suppliers/farmers, promotion of entrepreneurship and local firms, infrastructure development, for example, electricity, clean water, roads, clinics, microlending and access to capital and access to the legal system and social networks.

A final category of pro-poor CSR initiatives was derived from the analysis of empirical studies in developing countries (Gokulsing, 2011; Metzger et al., 2010; Renouard \& Lado, 2012): initiatives related to CSR organisation and decision making. According to these studies, for firms to increase their contribution to poverty alleviation the following actions should be implemented: collaborating with official agencies and NGOs, entrusting an independent foundation with the design and implementation of pro-poor CSR initiatives and considering poverty rates when making pro-poor CSR decisions at a corporate level.

\section{5 | Factors influencing a firm's contribution}

An analysis of the selected empirical studies suggests the existence of a wide range of factors determining a firm's contribution to poverty alleviation (see Table 4): (a) firm characteristics; (b) economic sector; (c) CSR effort and motivation; (d) stakeholders' interest, pressure and perception; (e) globalisation and governance deficits in developing countries; (f) national concern with poverty alleviation and perception of social justice. There follows a discussion of these categories of factors. In so doing, they will be compared with the drivers that have also been outlined by conceptual manuscripts (see Table 4).

Barkemeyer (2011) placed emphasis on the following characteristics of firms as factors explaining a manager's perceptions concerning the potential contribution of his/her firm to 23 sustainable 
TAB LE 4 Factors influencing a firm's contribution to poverty alleviation mentioned by empirical and conceptual research

\section{Factors from the review of empirical research}

Firm characteristics: size, geographic origin, Human Development Index, foreign direct investment

Economic sector: type of economic activity, CSR pattern in the industry

CSR effort and motivation: internal budgetary constraints, importance of in-group CSR as compared with universalist CSR, a core business-related motivation, a motivation to obtain legitimation to operate, a motivation to contribute to sustainable development goals, CSR strategy (reactive vs. proactive), management's satisfaction with pro-poor CSR

Stakeholders' interest, pressure and perception: the need for a higher standard of living for a firm's stakeholders in an operational environment; increased shareholder activism, NGO pressure and customer interest; perceptions of community representatives and key informants; CSR promises; issue salience of poverty; field cohesion; field distance

Globalisation and governance deficits in developing countries: failure of governments in developing countries to provide social services and development infrastructure, political regime, legal framework, government and firm corruption, Northern bias in the CSR agenda

National concern with poverty alleviation and perception of social justice: poverty rate, CSR standards, country priorities and development plans

Factors from the review of conceptual research

A possible positive impact on economic performance

A possible demand by stakeholders (e.g., community, including the poor)

A possible condition to gain social acceptance or "social licence" to operate

Headquarters' CSR decisions

Global and local contexts (in terms of economic, social, cultural and environmental conditions)

The ability and willingness of governments and civil society to fight against poverty

The regulatory system affecting CSR

\section{Author(s)}

Barkemeyer (2011), Gokulsing (2011), Metzger et al. (2010) and Valor (2012)

Barkemeyer (2011), Kolk et al. (2006), Ragodoo (2009) and Valor (2012)

Ite (2005), Lobel (2013), McIntyre et al. (2015), Metzger et al. (2010), Novelli and Hellwig (2011), Ragodoo (2009), Renouard and Lado (2012), Schölmerich (2013), Valor (2012) and Wuttke and Vilks (2014)

Gokulsing (2011), Idemudia (2007, 2009), Ite (2005), Lobel (2013), Mutana et al. (2013), Nguyen et al. (2018), Novelli and Hellwig (2011), Overton-de Klerk and Oelofse (2010), Ragodoo (2009), Raimi et al. (2015), Schölmerich (2013) and Valor (2012)

Amadi and Abdullah (2012), Barkemeyer (2011), Gokulsing (2011), Idemudia (2007, 2009), Ite (2005), Metzger et al. (2010), Ragodoo (2009), Raimi et al. (2015) and Renouard and Lado (2012)

Idemudia (2007, 2009), Lobel (2013), Metzger et al. (2010), Gokulsing (2011), Novelli and Hellwig (2011), Renouard and Lado (2012) and Valor (2012)

Author(s)

Porter and Kramer (2002) and Falck and Heblich (2007)

Clarkson (1995) and Medina-Muñoz et al. (2016)

Frynas and Yamahaki (2016), McIntyre et al. (2015) and Raimi et al. (2015)

Barkemeyer and Figge (2014) and Idemudia (2011)

Idemudia (2011)

Amadi and Abdullah (2012), Idemudia (2011), Idemudia and Kwakyewah (2018), Ite (2004) and Jamali, Lund-Thomsen, and Jeppesen (2017)

Bakan (2004), Banerjee (2014), Blowfield (2005) and Osuji and Obibuaku (2016) challenges, including that of poverty alleviation: size, geographic origin, Human Development Index (HDI). A firm's foreign direct investment was further suggested by Metzger et al. (2010) as a factor influencing the adoption of pro-poor CSR initiatives. Moreover, Valor (2012) mentioned both a firm's origin country and its host country as characteristics affecting the contribution of energy multinationals to poverty alleviation.

As shown in Table 4, the economic sector in which a firm operates was suggested as another factor explaining the firm's contribution to reducing poverty. For instance, Ragodoo (2009) found that the adoption of pro-poor CSR initiatives is more apparent in the hotel, sugar, investment and banking sectors in Mauritius. Kolk et al. (2006) also reported that multinationals in the garment and food processing sectors seem to be more committed to poverty reduction than those in the automobile and pharmaceutical industries. While the relative contribution to poverty alleviation of firms in a sector may change over time, these findings suggest that the economic sector affects a firm's contribution. As proposed by Kolk et al. (2006) and Valor (2012), firms may also adopt pro-poor CSR initiatives when other companies in the same sector are committed to poverty alleviation.

As regards CSR effort and motivation, Ite (2005) and Novelli and Hellwig (2011) pointed out that internal budgetary constraints affect a firm's contribution to poverty reduction. In addition, Lobel (2013) found that firms first adopt "in-group CSR" initiatives to reduce poverty amongst employees and then "universalist CSR" actions to reduce poverty at the community level. Three CSR motivations were also mentioned as factors influencing a firm's contribution: (a) a core business-related motivation (e.g., Lobel, 2013; Wuttke \& Vilks, 2014); (b) the gaining of a social licence to operate (e.g., Ite, 2005; Lobel, 2013; Mclntyre et al., 2015); (c) contribution to sustainable development goals (e.g., Valor, 2012).

These motivations are in line with those highlighted by conceptual manuscripts (see Table 4): (a) a possible positive impact on a firm's economic performance (i.e., the "win-win" approach); (b) a possible 
condition to gain social acceptance or "social licence" to operate in the community (i.e., the legitimisation approach); (c) a possible demand on the part of stakeholders, for example, communities, including the poor (i.e., the stakeholder approach). As regards the latter, empirical studies pointed out several factors that were grouped into the following category (see Table 4): stakeholders' interest, pressure and perception.

The need for a higher standard of living for a firm's stakeholders in an operational environment (e.g., owners, managers, employees and communities in developing countries) was cited as a factor influencing a firm's contribution to poverty alleviation (e.g., Ite, 2005; Raimi et al., 2015). Increased shareholder activism, NGO pressure, customer interest and community demand were also mentioned as drivers of propoor CSR (e.g., Ite, 2005; Novelli \& Hellwig, 2011; Overton-de Klerk $\&$ Oelofse, 2010). Three characteristics of stakeholders were further proposed by Lobel (2013): (a) issue salience of poverty (i.e., the extent to which poverty has meaning for stakeholders); (b) field cohesion (i.e., proximity and interconnectedness of powerful stakeholders at the national level); (c) field distance (i.e., proximity and interconnectedness of rich and poor). Lastly, Idemudia (2007) pointed out that local stakeholders expect multinationals to keep their CSR promises.

Another category of factors that was derived from the analysis of empirical studies was named "globalisation and governance deficits in developing countries" and included the following factors (see Table 4): failure of governments in developing countries to provide social services and development infrastructure (e.g., Amadi \& Abdullah, 2012; Raimi et al., 2015), political regime (e.g., Metzger et al., 2010), legal framework (e.g., Gokulsing, 2011), government and firm corruption (e.g., Idemudia, 2007; Metzger et al., 2010), Northern bias in the CSR agenda (e.g., Barkemeyer, 2011). All these factors were also suggested by conceptual manuscripts (see Table 4).

A final category of factors was outlined by empirical studies (see Table 4): "national concern with poverty alleviation and perception of social justice". In his model to predict organisational responsiveness to poverty, Lobel (2013) proposed that national concern with poverty positively affects in-group and universalist CSR. He also argued that firms in countries where social justice is limited to caring for in-group members will place more emphasis on in-group, rather than universalist CSR. Valor (2012) argued that national development priorities affect the adoption of CSR initiatives. Lastly, poverty rate and CSR awareness seem to positively affect a firm's adoption of propoor initiatives (e.g., Metzger et al., 2010; Renouard \& Lado, 2012).

\section{4 | THE INTEGRATED RESEARCH FRAMEWORK}

From a systematic review of conceptual and empirical studies on CSR for poverty alleviation, an integrated research framework is proposed. Figure 1 is an illustration of the proposed framework, which is intended to be useful for the design of future research and the assistance of the United Nations in achieving its poverty eradication goal. The framework consists of three sections: (a) the assessment of a firm's contribution to poverty alleviation as the independent variable in the proposed model; (b) types of pro-poor CSR initiatives that could be adopted by firms and (c) the factors influencing a firm's contribution as the independent variables. There follows a detailed description of the proposed framework and some recommendations for its application (see Table 5).

As regards the assessment of a firm's contribution to poverty alleviation, a novelty of the proposed framework is the inclusion of the three approaches that have been adopted by previous empirical research (see Figure 1 and Table 2): (a) content analysis of CSR initiatives; (b) the overall perceptions of residents, households, other local key informants, employees, managers and/or firms' other stakeholders (e.g., governmental officials, NGOs) and (c) the development and application of an assessment framework with a list of

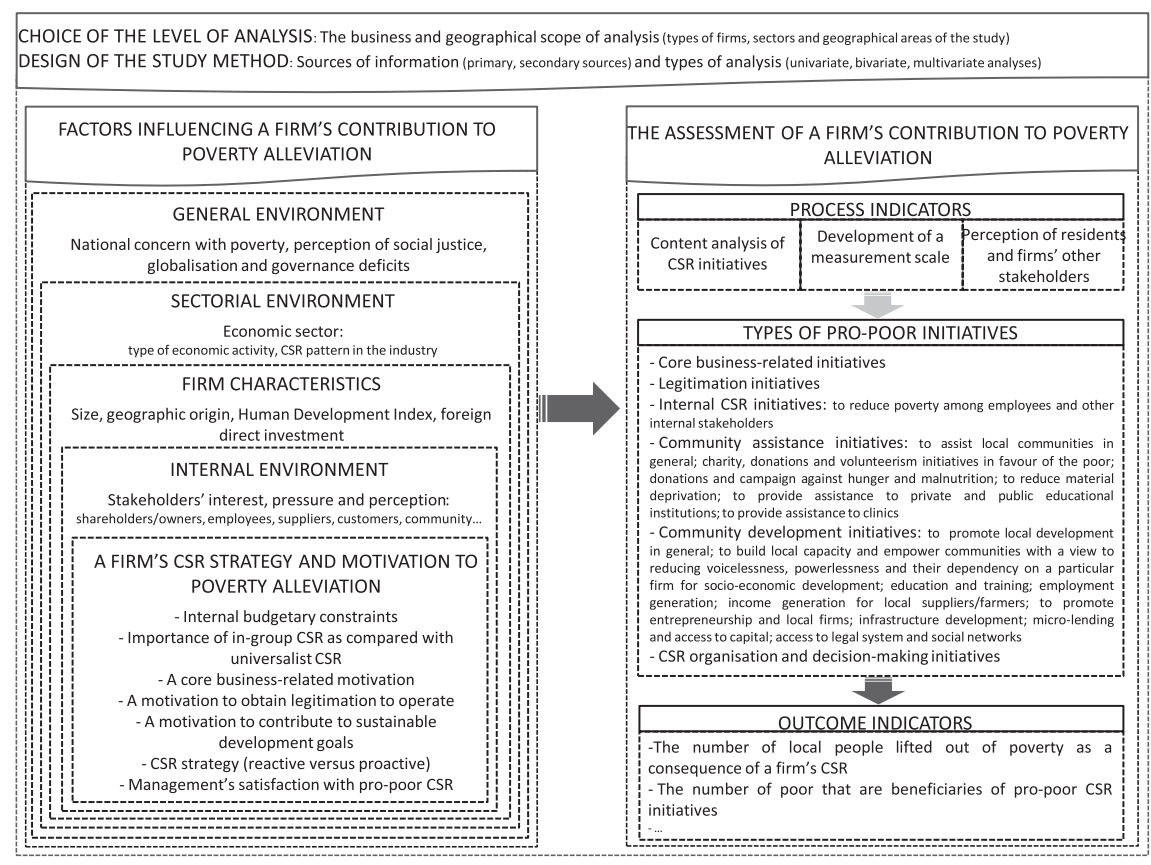

FIGURE 1 An integrative framework for empirical research on the contribution of firms to poverty alleviation 
TAB LE 5 Avenues for future research

Avenues related to the assessment of a firm's contribution to poverty alleviation

- To adopt outcome indicators when measuring a firm's pro-poor corporate social performance (e.g., the number of local people lifted out of poverty, the number of poor that are beneficiaries of CSR initiatives)

- To develop a reliable and validated scale for assessing the outcome of a firm's pro-poor CSR

- To evaluate the process of a firm's pro-poor CSR (e.g., investment, priorities, initiatives)

- To develop a reliable and validated scale for assessing the process of a firm's pro-poor CSR

- To adopt primary sources of information (e.g., interviews with poor residents and households, key informants and a firm's employees and managers) as a complement to secondary sources of information

- To empirically analyse the influence of specific pro-poor CSR initiatives on outcome indicators (i.e., a firm's ability to reduce poverty)

Avenues related to the factors influencing a firm's contribution to poverty alleviation

- To provide additional theoretical explanation of the specific factors that have been suggested by empirical studies (see Table 4)

- To generate additional empirical evidence regarding the influence of the different categories of factors on the outcome and process of a firm's pro-poor CSR

Avenues for the application of the proposed research framework as a whole

- To assess the contribution of different types of firms (e.g., multinationals, local large companies, SMEs) in a variety of economic sectors in one particular geographical area

- To apply the framework in a set of countries (e.g., the least developed countries) by gathering data and information regarding different types of firms in a variety of economic sectors

items. As stated by Wood $(1991,2010)$, there is a need for researchers to adopt outcome indicators when measuring CSP. Accordingly, the number of local people lifted out of poverty as a consequence of a firm's CSR or the number of poor that are beneficiaries of propoor CSR initiatives could be used when assessing a firm's pro-poor CSP. As proposed by the literature on development economics, the contribution of a firm's CSR to the HDI or a multidimensional measure of poverty that consider economic (e.g., income, consumption) and non-economic dimensions of poverty (e.g., living standard, social exclusion, access to education and health services, personal dignity, empowerment, vulnerability, distribution of income among the poor) could also be adopted. In so doing, firms are encouraged to report specific outcome indicators of their pro-poor CSR. Governments and international agencies could further promote the reporting of such indicators as part of a firm's CSR and sustainability reports.

Another recommendation is the development of reliable and validated scales for assessing the outcome and the process of a firm's pro-poor CSR. The basis for this recommendation is that the lack of any agreed research method for measuring a firm's commitment can adversely affect the generalisation of the empirical evidence (Hahn, 2012; Kolk et al., 2006). In addition, there is a need to evaluate not only the outcome of pro-poor CSR but also the process of such a social responsibility (e.g., pro-poor CSR priorities and initiatives) (Idemudia, 2007, 2011; Wood, 2010). The scale for assessing the process could be developed by considering the scales proposed by Kolk et al. (2006), Idemudia (2009) and Schölmerich (2013), as well as the different types of pro-poor initiatives identified in this study. As a further novelty, a wide variety of pro-poor CSR initiatives were derived from the analysis of the selected empirical studies. As shown in Figure 1 and Table 3, they can be grouped into the following categories: (a) core business-related initiatives; (b) legitimation initiatives; (c) internal CSR initiatives; (d) external CSR initiatives (i.e., community assistance and community development initiatives); (e) initiatives related to the CSR organisation and decision making.

Taking the above into consideration, a general recommendation for assessing a firm's contribution to poverty alleviation is to bring together outcome indicators (i.e., indicators of a firm's ability to lift local people out of poverty) and process indicators (i.e., the extent to which a firm adopts each of the pro-poor CSR initiatives included in a reliable and validated scale). Process indicators should be further empirically linked to outcome indicators. It could be interesting, for example, to analyse how specific pro-poor CSR initiatives affect a firm's ability to reduce poverty in a particular geographical area.

The application of the proposed assessment framework also requires the adoption of appropriate sources of information. A general recommendation is the adoption of primary sources of information, including interviews with a sample of poor residents and households, other residents, local key informants and a firm's employees and managers. The basis for this recommendation is that a firm's contribution to poverty alleviation cannot be easily measured by only using secondary sources of information: that is, the available data and information related to outcome indicators (e.g., the number of poor that are beneficiaries of a firm's pro-poor (SR) and process indicators (e.g., money spent in pro-poor CSR initiatives). This is evident in the case of small firms that do not publish CSR reports. The opinions of a firm's employees and managers represent an alternative approach to measuring the extent to which a firm contributes to poverty alleviation and adopts pro-poor CSR initiatives. There is also agreement concerning the need to consider the opinions of local communities, including the poor (Blowfield, 2007; Idemudia, 2011, 2014; Wood, 2010). The basis for this agreement is that the potential beneficiaries of a firm's pro-poor CSR are the most adequate source of information when evaluating the actual, rather than the intended, contribution of the firm to poverty alleviation.

Besides the assessment of a firm's contribution to poverty alleviation and the types of pro-poor CSR initiatives that could be adopted, the proposed framework includes a list of factors influencing a firm's contribution, which are the independent variables in the framework (see Figure 1 and Table 4). In fact, a major contribution of this study is the identification of an integrative list of factors explaining a firm's contribution to poverty reduction that were derived from the analysis of conceptual and empirical studies. A general conclusion is that empirical studies, as compared with major theoretical 
approaches to CSR ("win-win", stakeholder and legitimation approaches) and conceptual manuscripts, suggest a greater number of specific drivers of pro-poor CSR. The following categories of factors were derived from the analysis of empirical studies: (a) firm characteristics (e.g., size, geographic origin); (b) economic sector; (c) CSR effort and motivation (e.g., internal budgetary constraints, a core business-related motivation, a motivation to obtain legitimation to operate in a community); (d) stakeholders' interest, pressure and perception (e.g., increased shareholder activism, NGO pressure, customer interest and demand by community representatives); (e) globalisation and governance deficits in developing countries (e.g., legal framework, government and firm corruption, Northern bias in the CSR agenda); (f) national concern with poverty alleviation and perception of social justice (e.g., poverty rate, CSR standards, country development plans).

Considering the relevance of understanding the factors determining the contribution of firms to poverty alleviation, additional theoretical explanation of the factors influencing a firm's contribution to poverty alleviation is strongly recommended. In that respect, theoretical approaches from development economics could contribute to a better explanation of the link between CSR and poverty reduction by placing emphasis on the role that both states and markets should play with the purpose of increasing a firm's contribution to poverty. Another recommendation is the design of further empirical studies that aim to analyse the influence of the different categories of factors. Since these factors could help the United Nations, governments and development agencies to encourage firms to adopt pro-poor initiatives, these recommendations should be prioritised over the above mentioned recommendations related to the assessment of a firm's contribution to poverty alleviation.

\section{5 | CONCLUSIONS}

Relying on a critical analysis of both conceptual and empirical research articles on CSR for poverty alleviation, this study contributes to the emerging academic literature on the role of the private sector in reducing poverty by shedding light of avenues that need to be urgently researched. As argued above and shown in Table 5, this research highlights the need to develop reliable and validated scales for assessing the outcome and the process of a firm's pro-poor CSR, as well as to elaborate further theoretical and empirical research on the factors influencing a firm's outcome contribution to poverty alleviation.

Providing the findings of a timely review of the literature on the role of the private sector in reducing poverty, the proposed integrated research framework intends to be useful for facing the suggested avenues for future research. As regards the assessment of a firm's contribution to poverty alleviation, a novelty of the integrated research framework is the proposal of specific items that could be part of reliable and validated scales for assessing the outcome and the process of a firm's pro-poor CSR. The framework also places emphasis on the need to adopt primary sources of information and to identify the pro-poor CSR initiatives with the highest positive impact on a firm's outcome contribution.

With regard to the factors influencing a firm's contribution to poverty alleviation, a novelty of the framework is the inclusion of an integrative list of factors that was derived from the analysis of conceptual and empirical studies. Moreover, the framework suggests the need for further theoretical development that aims to explain the wide variety of specific factors that were identified in the review of empirical research articles.

Table 5 also provides recommendations for the application of the proposed integrated research framework as a whole. Since a firm's contribution to poverty alleviation, the types of pro-poor CSR initiatives with the highest potential contribution to reducing poverty and the factors influencing it vary across different business and geographical scopes, the adoption of several levels of analysis is recommended. For instance, the assessment of the contribution of different types of firms (e.g., multinationals, local large companies, SMEs) in all the economic sectors in one particular geographical area would be interesting.

Another recommendation is the design and implementation of an international research project that aims to apply the proposed framework as a whole by simultaneously evaluating its different sections: (a) the assessment of firms' contribution to poverty alleviation; (b) types of pro-poor CSR initiatives with the highest potential contribution to reducing poverty and (c) the factors influencing a firm's contribution. For example, the evaluation of the three sections of the framework in the least developed countries would be interesting by gathering data and information regarding different types of firms in a variety of economic sectors. The basis for this recommendation is the need to also assess the influence of the general environment (e.g., poverty rate, national concern with poverty, governance deficits) on a firm's contribution to poverty alleviation.

As regards firms' overall contribution to poverty alleviation, a general conclusion is that the findings of previous studies are not conclusive. For instance, while Schölmerich (2013), Mclntyre et al. (2015) and Raimi et al. (2015) reported a positive impact of the commitment of firms on the poverty level, Idemudia (2007), Waswa et al. (2009) and Renouard and Lado (2012) concluded that poverty remains endemic. The lack of consensus on the actual contribution of firms' CSR to poverty reduction justifies the need to generate further empirical evidence. Moreover, the evidence for corporate social contribution to poverty alleviation could help firms to assess the effectiveness of their pro-poor CSR initiatives. Development agencies could also consider the evidence for encouraging an adequate engagement of firms in alleviating poverty (UNDSD, 2015). As was discussed above, any attempt to generate further evidence should adopt adequate research methods (e.g., sources of information, the measuring of outcome and process indicators, analysis of how specific pro-poor CSR initiatives affect a firm's ability to reduce poverty in a particular geographical area).

In this context, the framework suggests implications for assisting the United Nations in achieving its poverty eradication goal. With the purpose of increasing firms' overall contribution to reducing poverty, 
the United Nations, governments and development agencies could encourage firms to adopt the specific pro-poor CSR initiatives that are shown in Table 3, including, for instance, community assistance and development initiatives in collaboration with official agencies, independent foundations and NGOs. In so doing, the different categories of factors influencing a firm's contribution to poverty alleviation must be considered (see Table 4). Besides encouraging governments to require certain legal standards regarding the adoption of pro-poor CSR initiatives, the United Nations could, for example, design and implement consciousness-raising programmes to increase the concern of governments and firms' other stakeholders with poverty alleviation.

Finally, the proposed integrated framework for assessing and explaining a firm's contribution to poverty alleviation, as well as the discussion of firms' overall contribution to poverty alleviation, are limited to the conceptual and empirical research articles on CSR for poverty alleviation that were analysed. In this respect, future research could consider further expanding the proposed framework using major theoretical approaches in the fields of CSR and development economics (e.g., the "win-win", stakeholder and legitimation approaches, dependency theories of development economics, liberal institutional pluralism) to strength the link between CSR and poverty reduction. For instance, more research is needed on integrating theories related to external and internal drivers of CSR in general and, in particular, for poverty alleviation (e.g., Frynas \& Yamahaki, 2016). Moreover, development economics theories could be adopted to further suggest the way both states and markets should work towards increasing the contribution of firms to poverty alleviation. As such, the literature on the BoP could be considered (e.g., Kolk et al., 2014; Prahalad, 2004; Prahalad \& Hammond, 2002; Prahalad \& Hart, 2002)

\section{CONFLICT OF INTERESTS}

The authors declare that they have no conflict of interests.

\section{ETHICAL APPROVAL}

This article does not contain any studies with human participants or animals performed by any of the authors.

\section{ORCID}

Diego R. Medina-Muñoz (iD https://orcid.org/0000-0002-0370-2353

\section{REFERENCES}

Amadi, B. O., \& Abdullah, H. (2012). Poverty alleviation through corporate social responsibility in Niger Delta. Nigeria. Asian Social Science, 8(4), 57-67. https://doi.org/10.5539/ass.v8n4p57

Arnold, D. G., \& Valentin, A. (2013). Corporate social responsibility at the base of the pyramid. Journal of Business Research, 66, 1904-1914. https://doi.org/10.1016/j.jbusres.2013.02.012
Bakan, J. (2004). The corporation: The pathological pursuit of profit and power. Toronto, Canada: Viking Canada.

Banerjee, S. B. (2008). Corporate social responsibility: The good, the bad and the ugly. Critical Sociology, 34(1), 51-79. https://doi. org/10.1177/0896920507084623

Banerjee, S. B. (2014). A critical perspective on corporate social responsibility: Towards a global governance framework. Critical Perspectives on International Business, 10(1/2), 84-95. https://doi.org/10.1108/ cpoib-06-2013-0021

Banerjee, S. B. (2018). Transnational power and translocal governance: The politics of corporate responsibility. Human Relations, 71(6), 796821. https://doi.org/10.1177/0018726717726586

Barkemeyer, R. (2009). Beyond compliance - below expectations? CSR in the context of international development. Business Ethics: A European Review, 18(3), 273-289. https://doi.org/10.1111/j.1467-8608. 2009.01563.x

Barkemeyer, R. (2011). Corporate perceptions of sustainability challenges in developed and developing countries: Constituting a CSR divide? Social Responsibility Journal, 7(2), 257-281. https://doi. org/10.1108/17471111111141521

Barkemeyer, R., \& Figge, F. (2014). CSR in multiple environments: The impact of headquartering. Critical Perspectives on International Business, 10(3), 124-151. https://doi.org/10.1108/cpoib-05-2013-0013

Blowfield, M. (2005). Corporate social responsibility: Reinventing the meaning of development? International Affairs, 81(3), 515-524. https ://doi.org/10.1111/j.1468-2346.2005.00466.x

Blowfield, M. (2007). Reasons to be cheerful? What we know about CSR's impact. Third World Quarterly, 28(4), 683-695.

Blowfield, M., \& Frynas, J. G. (2005). Setting new agendas: Critical perspectives on corporate social responsibility in the developing world. International Affairs, 81(3), 499-513.

Bradley, O. J., \& Botchway, G. O. (2018). Communicating corporate social responsibility (CSR) in the coffee industry: An examination of indicators disclosed. Sustainability Accounting, Management and Policy Journal, 9(2), 139-164. https://doi.org/10.1108/SAMPJ-02-20170015

Clarkson, M. B. E. (1995). A stakeholder framework for analyzing and evaluating corporate social performance. Academy of Management Review, 20(1), 92-117. https://doi.org/10.5465/amr.1995.95032 71994

Falck, O., \& Heblich, S. (2007). Corporate social responsibility: Doing well by doing good. Business Horizons, 50, 247-254. https://doi. org/10.1016/j.bushor.2006.12.002

Freeman, R. E. (1984). Strategic management: A stakeholder approach. Boston, MA: Pitman.

Friedman, M. (1962). Capitalism and freedom. Chicago: University Chicago Press.

Frynas, J. G., \& Yamahaki, C. (2016). Corporate social responsibility: Review and roadmap of theoretical perspectives. Business Ethics: A European Review, 25(3), 258-285. https://doi.org/10.1111/ beer.12115

Gokulsing, R. D. (2011). CSR matters in the development of Mauritius. Social Responsibility Journal, 7(2), 218-233. https://doi. org/10.1108/17471111111141503

Griffin, J. J. (2017). Tracing stakeholder terminology then and now: Convergence and new pathways. Business Ethics: A European Review, 26, 326-346.

Hahn, R. (2012). Inclusive business, human rights and the dignity of the poor: A glance beyond economic impacts of adapted business models. Business Ethics: A European Review, 21(1), 47-63. https://doi. org/10.1111/j.1467-8608.2011.01640.x

Idemudia, U. (2007). Community perceptions and expectations: Reinventing the wheels of corporate social responsibility practices in the Nigerian Oil Industry. Business and Society Review, 112(3), 369405. https://doi.org/10.1111/j.1467-8594.2007.00301.x 
Idemudia, U. (2009). Oil extraction and poverty reduction in the Niger Delta: A critical examination of partnership initiatives. Journal of Business Ethics, 90, 91-116. https://doi.org/10.1007/s10551-008-9916-8

Idemudia, U. (2011). Corporate social responsibility and developing countries: Moving the critical CSR research agenda in Africa forward. Progress in Development Studies, 11(1), 1-18. https://doi. org/10.1177/146499341001100101

Idemudia, U. (2014). Corporate social responsibility and development in Africa: Issues and possibilities. Geography Compass, 8(7), 421-435. https://doi.org/10.1111/gec3.12143

Idemudia, U., \& Kwakyewah, C. (2018). Analysis of the Canadian national corporate social responsibility strategy: Insights and implications. Corporate Social Responsibility and Environmental Management, 25(5), 928-938. https://doi.org/10.1002/csr.1509

Idemudia, U., \& Osayande, N. (2016). Assessing the effect of corporate social responsibility on community development in the Niger Delta: A corporate perspective. Community Development Journal, 53(1), 155-172.

Ite, U. E. (2004). Multinationals and corporate social responsibility in developing countries: A case study of Nigeria. Corporate Social Responsibility and Environmental Management, 11, 1-11. https://doi. org/10.1002/csr.49

Ite, U. E. (2005). Poverty reduction in resource-rich developing countries: What have multinational corporations got to do with it? Journal of International Development, 17, 913-929. https://doi.org/10.1002/ jid.1177

Jabbour, C. J. C., Neto, A. S., Freitas, W. R. S., Teixeira, A. A., \& da Silva, E. J. (2012). Organizations and the United Nations Millennium Development Goals: Evidence from some of the largest companies in Brazil. Humanomics, 28(1), 26-41. https://doi.org/10.1108/08288 661211200979

Jamali, D., \& Carroll, A. (2017). Capturing advances in CSR: Developed versus developing country perspectives. Business Ethics: A European Review, 26, 321-325.

Jamali, D., Lund-Thomsen, P., \& Jeppesen, S. (2017). SMEs and CSR in developing countries. Business \& Society, 56(1), 11-22. https://doi. org/10.1177/0007650315571258

Jamali, D., Lund-Thomsen, P., \& Khara, N. (2017). CSR institutionalized myths in developing countries: An imminent threat of selective decoupling. Business \& Society, 56(3), 454-486. https://doi. org $/ 10.1177 / 0007650315584303$

Kolk, A., Rivera-Santos, M., \& Rufin, C. (2014). Reviewing a decade of research on the 'base/bottom of the pyramid' (BOP) concept. Business \& Society, 53(3), 338-377. https://doi.org/10.1177/0007650312 474928

Kolk, A., van Tulder, R., \& Westdijk, B. (2006). Poverty alleviation as business strategy? Evaluating commitments of frontrunner multinational corporations. World Development, 34(5), 789-801. https://doi. org/10.1016/j.worlddev.2005.10.005

Lobel, S. (2013). Predicting organizational responsiveness to poverty: Exploratory model and application to Brazil and the United States. European Management Journal, 31, 522-535. https://doi. org/10.1016/j.emj.2013.04.007

Luo, X. M., \& Bhattacharya, C. B. (2006). Corporate social responsibility, customer satisfaction, and market value. Journal of Marketing, 70(4), 1-18. https://doi.org/10.1509/jmkg.70.4.001

Maignan, I., \& Ferrell, O. C. (2000). Measuring corporate citizenship in two countries: The case of the United States and France. Journal of Business Ethics, 23, 283-297.

Margolis, J., \& Walsh, J. (2003). Misery loves companies: Rethinking social initiatives by business. Administrative Science Quarterly, 48, 268305. https://doi.org/10.2307/3556659

McIntyre, M. L., Murphy, S. A., \& Sirsly, C.-A. T. (2015). Do firms seek social licence to operate when stakeholders are poor? Evidence from Africa. Corporate Governance, 15(3), 306-314.
Medina-Muñoz, D. R., Medina-Muñoz, R. D., \& Gutiérrez-Pérez, F. J. (2016). A sustainable development approach to assessing the engagement of tourism enterprises in poverty alleviation. Sustainable Development, 24(4), 220-236. https://doi.org/10.1002/sd.1624

Merino, A., \& Valor, C. (2011). The potential of corporate social responsibility to eradicate poverty: An ongoing debate. Development in Practice, 21(2), 157-167. https://doi.org/10.1080/09614 524.2011.546005

Metzger, L., Nunnenkamp, P., \& Mahmoud, T. O. (2010). Is corporate aid targeted to poor and deserving countries? A case study of Nestlé's aid allocation. World Development, 38(3), 228-243. https://doi. org/10.1016/j.worlddev.2009.09.005

Mutana, S., Chipfuva, T., \& Muchenje, B. (2013). Is tourism in Zimbabwe developing with the poor in mind? Assessing the pro-poor involvement of tourism operators located near rural areas in Zimbabwe. Asian Social Science, 9(5), 154-161. https://doi.org/10.5539/ass. v9n5p154

Nguyen, N., Boruff, B., \& Tonts, M. (2018). Fool's gold: Understanding social, economic and environmental impacts from gold mining in Quang Nam Province. Vietnam. Sustainability, 10(1355), 1-22. https ://doi.org/10.3390/su10051355

Novelli, M., \& Hellwig, A. (2011). The UN Millennium Development Goals, tourism and development: The tour operators' perspective. Current Issues in Tourism, 14(3), 205-220. https://doi.org/10.1080/13683 500.2011.555523

Okpara, J. O., \& Wynn, P. M. (2012). Stakeholders' perceptions about corporate social responsibility: Implications for poverty alleviation. Thunderbird International Business Review, 54(1), 91-103. https://doi. org/10.1002/tie.21441

Osuji, O. K., \& Obibuaku, U. L. (2016). Rights and corporate social responsibility: Competing or complementary approaches to poverty reduction and socioeconomic rights? Journal of Business Ethics, 136, 329-347. https://doi.org/10.1007/s10551-014-2523-y

Overton-de Klerk, N., \& Oelofse, E. (2010). Poor communities as corporate stakeholders: A bottom-up research approach. Communicatio, 36(3), 388-408. https://doi.org/10.1080/02500167.2010.518797

Pater, A., \& van Lierop, K. (2006). Sense and sensitivity: The roles of organisation and stakeholders in managing corporate social responsibility. Business Ethics: A European Review, 15(4), 339-351. https://doi. org/10.1111/j.1467-8608.2006.00461.x

Porter, M. E., \& Kramer, M. R. (2002). The competitive advantage of corporate philanthropy. Harvard Business Review, 80(12), 56-68.

Prahalad, C. K. (2004). The fortune at the bottom of the pyramid: Eradicating poverty through profits. Upper Saddle River, NJ: Wharton School Publishing.

Prahalad, C. K., \& Hammond, A. (2002). Serving the world's poor, profitability. Harvard Business Review, 80(9), 48-57.

Prahalad, C. K., \& Hart, S. L. (2002). The fortune at the bottom of the pyramid. Strategy + Business, 26, 1-14

Ragodoo, N. J. F. (2009). CSR as a tool to fight against poverty: The case of Mauritius. Social Responsibility Journal, 5(1), 19-33. https://doi. org/10.1108/17471110910939971

Raimi, L., Akhuemonkhan, I., \& Ogunjirin, O. D. (2015). Corporate social responsibility and entrepreneurship (CSRE): Antidotes to poverty, insecurity and underdevelopment in Nigeria. Social Responsibility Journal, 11(1), 56-81. https://doi.org/10.1108/SRJ-11-2012-0138

Renouard, C., \& Ezvan, C. (2018). Corporate social responsibility towards human development: A capabilities framework. Business Ethics: A European Review, 27, 144-155.

Renouard, C., \& Lado, H. (2012). CSR and inequality in the Niger Delta (Nigeria). Corporate Governance, 12(4), 472-484. https://doi. org/10.1108/14720701211267810

Rodrigo, P., Duran, I. J., \& Arenas, D. (2016). Does it really pay to be good, everywhere? A first step to understand the corporate social and financial performance link in Latin American controversial industries. 
Business Ethics: A European Review, 25(3), 286-309. https://doi. org/10.1111/beer.12119

Schölmerich, M. J. (2013). On the impact of corporate social responsibility on poverty in Cambodia in the light of Sen's capability approach. Asian Journal of Business Ethics, 2, 1-33. https://doi.org/10.1007/ s13520-012-0016-6

United Nations Conference on Trade and Development. (2014). Social inclusion programmes and inclusive growth in developing countries. Note by the UNCTAD Secretariat, 18 September.

United Nations Division for Sustainable Development. (2015). Transforming our world: The 2030 United Nations agenda for sustainable development. Geneva, Switzerland: United Nations.

Valor, C. (2012). The contribution of the energy industry to the Millennium Development Goals: A benchmark study. Journal of Business Ethics, 105, 277-287. https://doi.org/10.1007/s10551-011-0970-2

Vashchenko, M. (2017). An external perspective on CSR: What matters and what does not? Business Ethics: A European Review, 26, 396-412.

Voltan, A., Hervieux, C. H., \& Mills, A. (2017). Examining the win-win proposition of shared value across contexts: Implications for future research. Business Ethics: A European Review, 26, 347-368.

Waswa, F., Netondo, G., Maina, L., Naisiko, T., \& Wangamati, J. (2009). Potential of corporate social responsibility for poverty alleviation among contract sugarcane farmers in the Nzoia Sugarbelt, Western Kenya. Journal of Agricultural and Environmental Ethics, 22, 463-475. https://doi.org/10.1007/s10806-009-9165-6

Wood, D. J. (1991). Corporate social performance revisited. Academy of Management Review, 16(4), 691-718. https://doi.org/10.5465/ amr.1991.4279616

Wood, D. J. (2010). Measuring corporate social performance: A review. International Journal of Management Reviews, 12(1), 50-84. https:// doi.org/10.1111/j.1468-2370.2009.00274.x
World Commission on Environment and Development. (1987). Our common future: The report of the World Commission on Environment and Development. Oxford, UK: Oxford University Press.

Wuttke, M., \& Vilks, A. (2014). Poverty alleviation through CSR in the Indian construction industry. Journal of Management Development, 33(2), 119-130. https://doi.org/10.1108/JMD-11-2013-0150

\section{AUTHOR BIOGRAPHIES}

Rita D. Medina-Muñoz is professor of organizational behavior and hospitality management at the University of Las Palmas de Gran Canaria and her research focuses on sustainable development, CSR, competitiveness, innovation and control.

Diego R. Medina-Muñoz is professor of hospitality and destination strategic management at the University of Las Palmas de Gran Canaria. He collaborates with major international organizations specialised on tourism, including UNWTO and UNCTAD.

How to cite this article: Medina-Muñoz RD, Medina-Muñoz DR. Corporate social responsibility for poverty alleviation: An integrated research framework. Business Ethics: A Eur Rev. 2020;29:3-19. https://doi.org/10.1111/beer.12248 